AJChE 2016, Vol. 16, No. 2, $01-07$

\title{
Natural Surfactant from Fatty Acid of Morinda citrifolia L. for Deinking Flotation
}

Trismawati ${ }^{\star, 1,2}$

I.N.G. Wardana ${ }^{1}$

Nurkholis Hamidi ${ }^{1}$

Mega Nur Sasongko ${ }^{1}$

${ }^{1}$ Department of Mechanical Engineering, Universitas Brawijaya, Malang, Indonesia

2 Faculty of Engineering, Universitas Panca Marga, Probolinggo, Indonesia

*e-mail: trismawati@upm.ac.id

Natural surfactant is developed as fatty acid derivate from natural resources such as palm oil, sunflower oil, and safflower oil. In South East Asia countries, the palm oil is used as the main resources of fatty acid derivate. Seed oil of Morinda citrifolia $L$. contains unsaturated fatty acid. It is extracted and concentrated. The concentrated fatty acid of Morinda citrifolia L. (CFAMC) is used as deinking surfactant. The CFAMC is analyzed by GCMS for its constituent and its deinking flotation performance is evaluated for yield, brightness, and ERIC of deinked pulp. Based on the old newspaper (ONP) pulp with brightness of 35.84 ISO, and ERIC of 1982.4 ppm, the deinking flotation performance of CFAMC is approaching the natural surfactant. The brightness increase is $11.36 \%$ and $16.35 \%$, and the ERIC reduction is $37.40 \%$ and $47.73 \%$ for CFAMC and natural surfactant respectively. SEM analysis is provided to see the residual Nanoink particles on the fibers.

Keywords: Natural Surfactant, CFAMC, Brightness, ERIC, Yield

\section{INTRODUCTION}

Natural surfactant has compatible advantages than synthetic surfactant. It is extracted by simple process with low risk to environmental degradation. Synthetic surfactant is produced via complex process and has environmental harm-full side product such as benzene and phenol. Synthetic surfactants are slow biodegradable. In conventional deinking, the chemicals used give additional effort in the effluent treatment. Enzyme and surfactant is also applied together in deinking process, but does not reduce the environmental problems significantly.

\section{THEORY}

Studying deinking flotation has two main purposes, to get deinked pulp and to protect environment. A good quality of deinked pulp should be achieved in low risk of environment pollution. Most deinking flotation study is concern the effect of chemicals, enzyme, and surfactant to the quality of deinked pulp. Researches of enzyme and surfactant for flotation deinking have been done (Darm 2012, Jeffries 1994, Kim 1991). Enzyme is 
able to release fibril from ink surface and change the hydrophobic properties of ink (Kim 1991).

Conventional deinking does not able to remove effectively the ink that has been polymerized and attached into the fiber structure. A mixture of cellulase, xylanase, amylase, and lipase is able to increase pulp brightness and to reduce ERIC significantly (Darm 2012). Other research explain, the surfactant with longer hydrocarbon chain gain better result than the shorter one (Khalek 2012), surfactant with high HLB value is favorable for cellulase activity and low HLB value is favorable for ink removal efficiency (Mayeli 2010).

Fatty acid as the main constituent of natural oil is biodegradable. It is extracted from many seeds such as safflower, sunflower, soybean, and palm oil (Boyle 2007), and red palm olein, palm olein, corn oil, and coconut oil (Eqbal 2011). Natural surfactant is fatty acid derivate and the deinking performance depends on its modification (Hannuksela 2008). Fatty acid based surfactant has carboxylic head and hydrocarbon tail. The carboxylic head has hydrophilic characters; the hydrocarbon tail has hydrophobic characters. Natural surfactant is normally a mixture of several fatty acids with different structures such as palmitic acid, stearic acid, palmitoleic acid, oleic acid, linoleic and, and linolenic acid (Hannuksela 2008). The total unsaturated fatty acid of safflower oil, sunflower oil and corn oil are $91 \%, 89 \%$, and $87 \%$ with the poly-unsaturated fatty acid content of 78 $\%, 69 \%$ and $62 \%$ respectively. These values are above other vegetable oil such as soybean and palm that mostly viewer than
$60 \%$, and for coconut is $8 \%$ (Boyle 2007).

Morinda citrifolia $L$. has been used for pharmacy and folk medicine, but its seed is rarely evaluated for industrial chemical. Fatty acid compound of Morinda citrifolia $L$. oil is belongs to the high polyunsaturated. The total unsaturated fatty acid of Morinda citrifolia L. oil is $81.2 \%$ (Desai 2011, Eqbal 2011) and its fatty acids composition is $18.8 \%, 14.6 \%$ and $66.6 \%$ of saturated, mono-unsaturated and polyunsaturated respectively (Desai 2011). In this research the Morinda citrifolia $L$. seed oil is used as surfactant. It will be proved in its performance as an eco-friendly product.

\section{EXPERIMENT}

The materials used are the seed of Morinda citrifolia L. and ONP (collected from local area); n-hexane, $\mathrm{H}_{2} \mathrm{SO}_{4} 1.0 \%$ in methanol solution, $\mathrm{NaHCO}_{3}$, sodium lauryl sulfate (Merck); and papyrase enzyme, natural surfactant (PT KAO Indonesia).

Tree step experiments were required:

\section{Fatty acid preparation step}

The dried seed powder of Morinda citrifolia $L$. was extracted using $n$-hexane in soxhlet extractor. Extraction was performed for 4, 6, and 8 hours. The fatty acid was concentrated by rotary vacuum evaporator of IKA@RV 10 digital and used as surfactant for deinking flotation. The CFAMC was isolated for fatty acid and analyzed with GCMS of QP 2010 S for its constituent. 


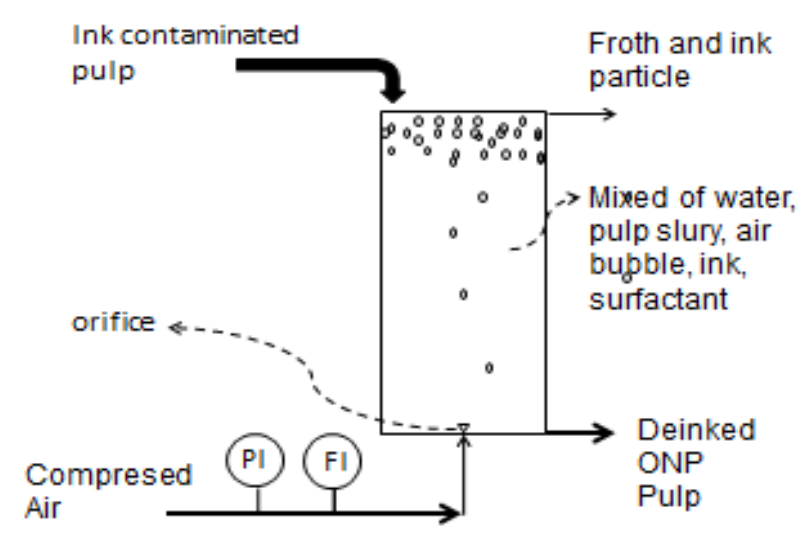

Fig. 1: Equipment set up for Deinking Flotation

\section{Pulping step}

ONP was torn into small pieces, and 50 $\mathrm{g}$ of ONP was disintegrated in $0.9 \mathrm{~L}$ of water for $10 \mathrm{~min}$ at $2000 \mathrm{rpm}$ of high speed mixer, at $30{ }^{\circ} \mathrm{C}$ and $\mathrm{pH}$ 7. The pulp was poured into a collecting flask, and the disintegrator was rinsed with $0.1 \mathrm{~L}$ of washing water. The pulp was kept at $5 \%$ consistency.

\section{Flotation step}

The equipment setup for flotation is presented in figure 1 . The pulp sample $(500 \mathrm{~mL})$ was poured into a flotation tank filled with $5 \mathrm{~L}$ of water so that $0.5 \%$ consistency was reached. Then, $0.15 \%$ of natural surfactant, $0.6 \%$ of sodium lauryl sulfate, and $1 \%$ of papyrase enzyme were mixed in the pulp slurry for 10 min before the pulp was floated into the flotation tank (Trismawati 2015). Flotation was carried out for $10 \mathrm{~min}$ at $\mathrm{pH} \mathrm{7,} \mathrm{temperature} \mathrm{of}$ $30^{\circ} \mathrm{C}$, with air flow rate of 7.5 liter/minute and 30 psig constant pressures. The inkcontaminated froth was removed from the upper part of the flotation tank. The deinked pulp was drained from the bottom part of the flotation tank and washed over a 48 mesh screen, and made into a sheet using hand-sheet maker (Tappi T 218-om 91). The deinking performance was evaluated for brightness and ERIC with a Technidyne Color Touch 2 model ISO for optical properties evaluation. The ink particles deposited on the fiber surfaces were evaluated with Scanning Electron Microscope (SEM) FEI type inspect S-50. The same experiment was also performed for CFAMC.

\section{RESULT AND DISCUSSION}

The soxhlet extraction times was varied for 4, 6, and 8 hours. As it was presented in Table 1, soxhlet extraction time has significant effects on the CFAMC constituent.

The 4 hour soxhlet extraction time provided short unsaturated hydrocarbon chain of (C6:1) and a few of (C5:1), the 6 hour soxhlet extraction time provided high amount of long unsaturated hydrocarbon chain of (C19:2) and a few of (C6:1), and 8 hour soxhlet extraction time provided 
Table 1. GCMS of CFMAC

\begin{tabular}{|c|c|c|c|c|c|}
\hline GC & & & MS & & \\
\hline $\begin{array}{l}\text { Abundance } \\
\text { (\% oF TIC) }\end{array}$ & Compounds & $\begin{array}{l}\text { Molecule } \\
\text { Weight }\end{array}$ & $\begin{array}{l}\text { Molecule } \\
\text { Formula }\end{array}$ & $\begin{array}{c}\text { Number of } \\
\text { Double Bond/ } \\
\text { Molecule }\end{array}$ & $\begin{array}{l}\text { Quantity } \\
\% \text { of Peak }\end{array}$ \\
\hline $\mathrm{TIC}=80.00$ & of 4 hour extraction & & & & \\
\hline 1615 & Isobutyl alcohol & 74 & $\mathrm{C}_{4} \mathrm{H}_{10} \mathrm{O}$ & - & 8 \\
\hline 10,15 & Butenoic acid & 100 & $\mathrm{C}_{5} \mathrm{H}_{8} \mathrm{O}_{2}$ & 1 & 15 \\
\hline 857 & Nitropropane & 89 & $\mathrm{C}_{3} \mathrm{H}_{7} \mathrm{NO}_{2}$ & - & Trace \\
\hline 0,51 & 3 Hexenol & 100 & $\mathrm{C}_{6} \mathrm{H}_{12} \mathrm{O}$ & 1 & 2 \\
\hline 75,27 & $\begin{array}{l}\text { 1,3 Dicyclopenyl-2- } \\
\text { Dodecycle }\end{array}$ & 374 & $\mathrm{C}_{27} \mathrm{H}_{50}$ & - & Trace \\
\hline $\mathrm{TIC}=9.000$ & 00 of 6 hour extraction & & & & \\
\hline 236 & Metyl 9, 10 Dideutero & 298 & $\mathrm{C}_{19} \mathrm{H}_{36} \mathrm{D}_{2} \mathrm{O}_{2}$ & 1 & Trace \\
\hline $3, \angle 0$ & Metyl Butanoate & 102 & $\mathrm{C}_{5} \mathrm{H}_{10} \mathrm{O}_{2}$ & - & Trace \\
\hline 0674 & 9,12 Octadecadienoic acid & 294 & $\mathrm{C}_{19} \mathrm{H}_{34} \mathrm{O}_{2}$ & 2 & 13 \\
\hline & Hexenol & 100 & $\mathrm{C}_{6} \mathrm{H}_{12} \mathrm{O}$ & 1 & 1 \\
\hline $\mathrm{TIC}=14.00$ & 000 of 8 hour extraction & & & & \\
\hline 217 & Pentadecanoic acid & 270 & $\mathrm{C}_{17} \mathrm{H}_{34} \mathrm{O}_{2}$ & - & 15 \\
\hline 2,13 & Tetradecanoic acid & 256 & $\mathrm{C}_{16} \mathrm{H}_{32} \mathrm{O}_{2}$ & - & 25 \\
\hline & Methyl Heptanoate & 144 & $\mathrm{C}_{8} \mathrm{H}_{16} \mathrm{O}_{2}$ & - & Trace \\
\hline 9787 & 9,12 Octadecadienoic acid & 294 & $\mathrm{C}_{19} \mathrm{H}_{34} \mathrm{O}_{2}$ & 2 & 20 \\
\hline & 11,14 - Eicosadienoic acid & 322 & $\mathrm{C}_{21} \mathrm{H}_{38} \mathrm{O}_{2}$ & 2 & Trace \\
\hline
\end{tabular}

higher amount of (C19:2) and a few of (C16:0) and (C17:0). This finding support a suggestion that the lipophilic part of long chain hydrocarbon with its unsaturated structure gives higher lipophilic properties that made them has higher accessibility to ink molecules. This facts support the suitability of CFAMC for natural surfactant (Hannuksela 2008, Lasus 2000).

The performance of CFAMC provided a good result for brightness, ERIC, and yield. It was established that soxhlet extraction time of 6 hours produced CFAMC that provided deinked pulp with high brightness of 43.83 ISO (see Figure 2) and low ERIC of 732 ppm (see Figure 3) with high yield of $79.8 \%$. The control pulp itself has brightness, ERIC and yield of 45.5
ISO, $677.9 \mathrm{ppm}$, and $78.4 \%$ respectively.

As brightness measurement could not be used to judge for the efficiency of ink removal (www.technidyne.com), ERIC measurement was provided. The result shows in figure 2 indicate that CFAMC has a good surfactant characteristic and could be used as flotation surfactant (Hannuksela 2008, Lasus 2000) even though certain character should be modified for being less lipophilic and more hydrophilic. The (C19:2) of 6 hour extraction time was provided high brightness and lowest ERIC with highest yield as compared with others, even though the ERIC still higher than control.

The results shown in figure 2 illustrate that fatty acid with long unsaturated 
hydrocarbon is appropriate or deinking flotation surfactant. This because, the longer the hydrocarbon chain presence in the surfactant, the more hydrophobic character the surfactant has (Khalek 2012), promote better interaction between surfactant and ink particles. Figure $\mathbf{3}$ shows the optimum dosage was $1.5 \%$ for both natural surfactant and CFAMC. In agreement with the length of hydrocarbon
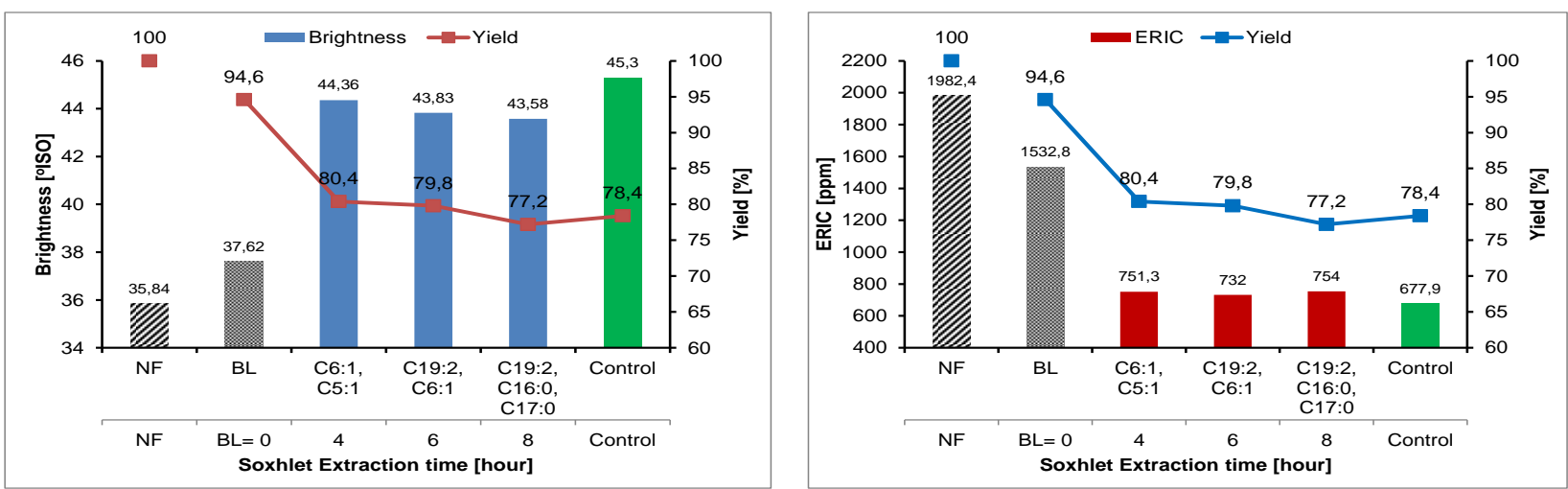

Fig.2 : Brightness, ERIC, and yield of deinked pulp after flotation with CFAMC extracted for 4, 6, 8 hour (with main constituent as listed on the axis); NF is un-floated ONP pulp and BL deinked pulp with flotation only.

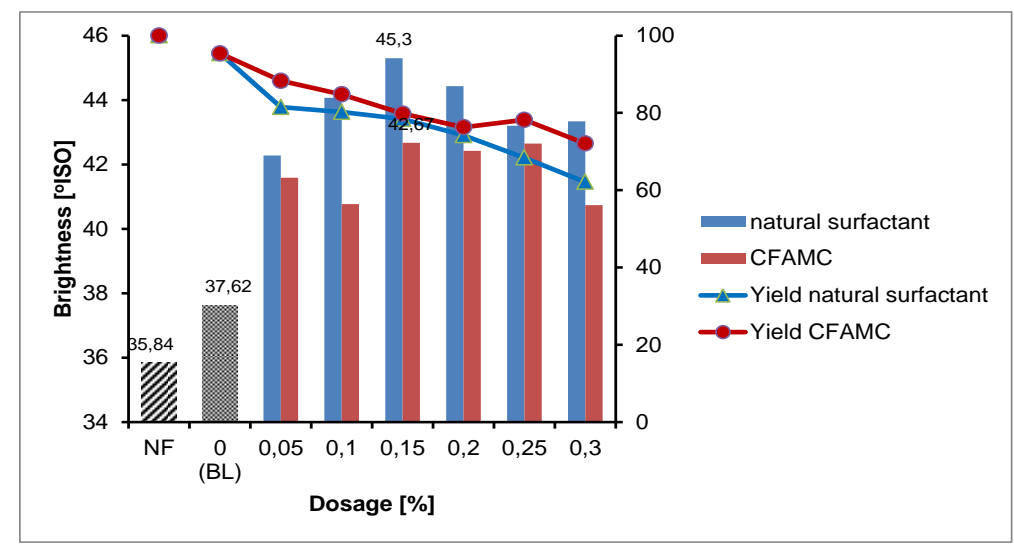

(a)

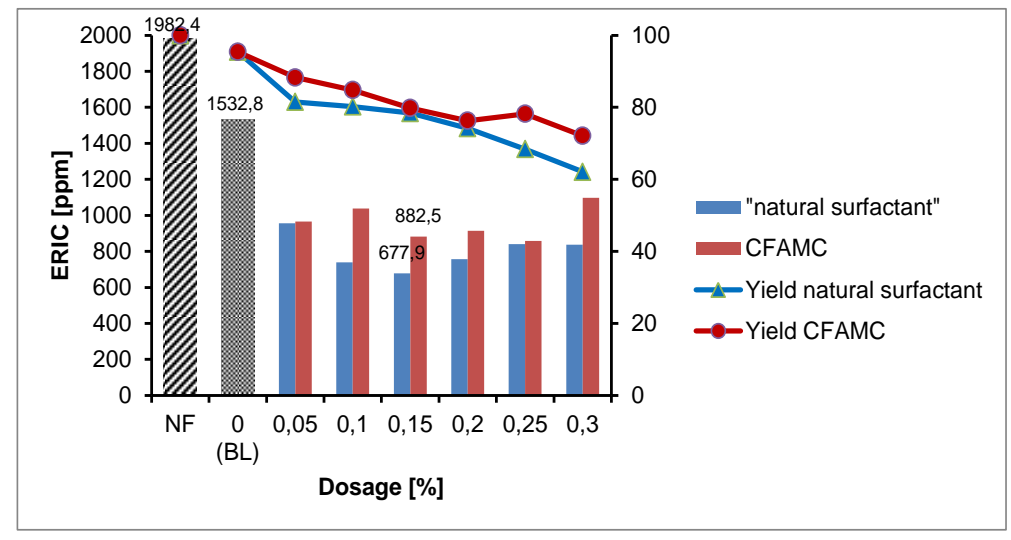

(b)

Fig.3 : Brightness, ERIC, and yield of deinked pulp after flotation with difference dosage of CFAMC and natural surfactant. 

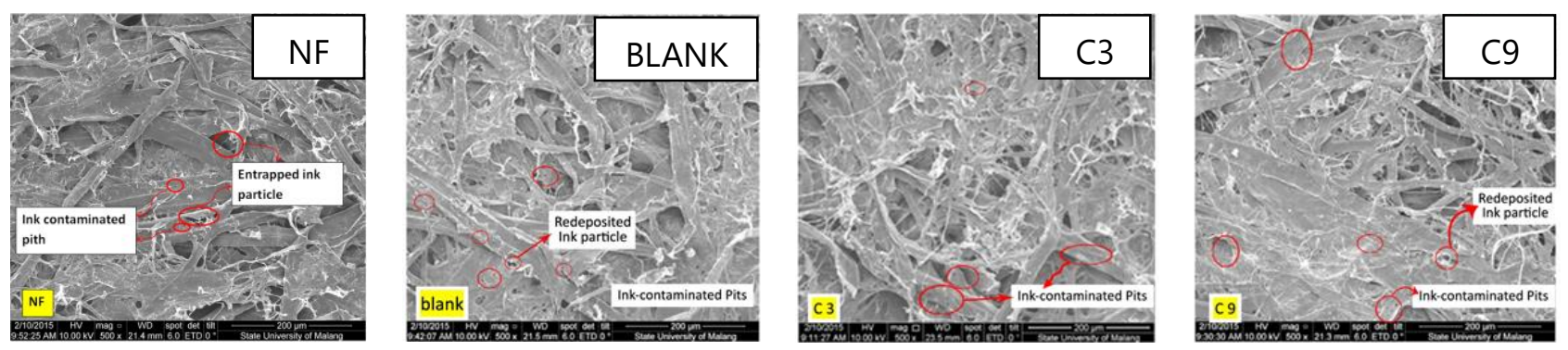

Fig.4 : SEM of ONP pulp (NF), deinked pulp floated with air bubbles only (blank), deinked pulp floated with natural surfactant (C3), and deinked pulp floated with CFAMC (C9).

chain, the two double bonds present in C19:2 will improve the accessibility and bonding ability of CFAMC into ink structure. This promotes high brightness and lowest ERIC with high yield. The hydrogen bond exist in the hydrophilic part of CFAMC that should be improved for better accessibility into water molecule and bubbles - water interface is another thing that should be elucidate later.

Figure 4 presents SEM of sheet of ONP pulp and deinked pulp. The black spot is the re-deposited ink particles and ink entrapped inside the slit or in fiber pore (piths). SEM of ONP pulp (NF) was darker than others. The finely distributed ink on the fiber surface of blank sheet keep higher than of C3 (natural surfactanttreated) and of C9 (CFAMC-treated). In the blank sheet (blank), the black spot on the sheet is invisible because ink particles still evenly distributes on the sheet surface. In case of C3 (natural surfactant-treated) and C9 (CFAMC-treated) the black spot on the sheet is clearly seen, the finely distributed ink on the fiber surface had been partially removed and the ink on the fiber pore (pith) did not effectively removed, made them darker than surrounding. The black spot on C3 was seems lighter than on C9, this mean the ink removal from fiber surface and pith was better. The lipophilic properties of CFAMC assist the ink particles removal (Mayeli 2010) but the trapped ink in the pith and rough surfaces was removed un-effectively. From this condition, it can be inferred that CFAMC can be used as surfactant but the deinking power is below natural surfactant.

\section{CONCLUSION}

1. Soxhlet extraction time of 6 hours has established CFAMC with fatty acid constituent suitable for natural surfactant with low risk of fiber lost.

2. The deinking power of CFAMC is still below natural surfactant.

3. Fatty acid of C19:2 is able to promote good surfactant character for flotation deinking, give deinked pulp with high brightness of 43,83 ISO and low ERIC of $732 \mathrm{ppm}$ in high yield of $79,8 \%$ with optimum dosage of $1.5 \%$

4. CFAMC has a good surfactant characteristic even though certain character should be modified for being less lipophilic and more hydrophilic (HLB value should be adjusted). 


\section{ACKNOWLEDGEMENT}

The authors are grateful for the financial support of the Ministry of Research Technology and Higher Education (DIKTI), Grant. No: 1014/UN10.14/KU/2013; PT KAO Indonesia Branch Surabaya for Papyrase enzyme and natural surfactant; Darono Wikanaji for his intellectual thinking during discussion.

\section{REFERENCES}

1. Boyle, M. A. and Anderson, S. L. (2010). Personal Nutrition $7^{\text {th }}$ ed., Thomson Wadsworth, Australia, p 132.

2. Desai, N., Dattatraya K G., and Chavan, P.D. (2011). Fatty acid profile of seed oil of Morinda species growing in different habitats, Journal of Pharmacy Research, 4(3), 841-842.

3. Dharm, D., Tyagi, C. H., Singh, R. P., and Kumar, A. (2012). Effect of Enzyme Concoctions on Fiber Surface Roughness and Deinking Efficiency of Shorted Office Paper, Cellulose Chemistry and Technology, 46 (9-10), 611-623.

4. Eqbal D., Halimah, A.S., Aminah A. and Zhalifah, M.K., (2011). Fatty acid composition of four difference vegetable oils (Red palm olein, palm olein, corn oil and coconut oil) by gas chromatography, $2^{\text {nd }}$ International Conference on Chemistry and
Chemical Engineering, IPCBEE vol. 14, 31-34. Singapore: IACSIT Press.

5. Hannuksela, T. and Rosencrance, S. (2008). Deinking Chemistry, Scientific Reports of Working Group Meetings, Kemira Germany $\mathrm{GmbH}$ and Kemira Chemicals Inc., unpublished.

6. Jeffries (1994). Comparison of enzyme enhanced with conventional deinking of xerographic and laser-printed paper, Tappi Journal, 77 (4), 173.

7. Khalek, M. A. (2012). Performance of different surfactants in deinking flotation process, Elixir Appl. Chem., 46, 8147-8151.

8. Kim (1991). Enzymatic deinking method of waste paper, Proceeding of Tappi Pulping conference, 1023 1031.

9. Lassus, A. (2000). Recycle Fiber and Deinking, Papermaking Science and Technology, vol. 7, Lothar Göttsching and Heikki Pakarinen ed., Fapet Oy, Finland. $241-265$.

10. Mayeli and Talaeipour (2010). Effect of difference HLB value and enzymatic treatment on the properties of old newspaper deinked pulp, Bioresources, 5(4), $2520-2534$.

11. Trismawati, Wardana, I.N.G., Hamidi, N., and Sasongko, M. N. (2015). Characteristic of Flotation Deinking Using Bio and Synthetic Surfactant at Different Air Flow Rate, $4^{\text {th }}$ ICESEAM International Conference, The Alana Hotel, Surakarta.

12. www.technidyne.com 